\title{
SCRIB wt Allele
}

National Cancer Institute

\section{Source}

National Cancer Institute. SCRIB wt Allele. NCI Thesaurus. Code C125583.

Human SCRIB wild-type allele is located in the vicinity of $8 \mathrm{q} 24.3$ and is approximately 24

$\mathrm{kb}$ in length. This allele, which encodes protein scribble homolog, plays a role in the differentiation of polarized cells. 